Weed Control in Sunflower (Helianthus annuus L.) with Soil-applied Herbicides Affected by a Prolonged and Limited rainfall

Nadzor korova u suncokretu (Helianthus annuus L.) zemljišnim herbicidima pod utjecajem dugotrajnih i ograničenih oborina

Pacanoski, Z., Mehmeti, A.

Poljoprivreda/Agriculture

ISSN: $1848-8080$ (Online)

ISSN: 1330-7142 (Print)

https://doi.org/10.18047/poljo.27.2.1

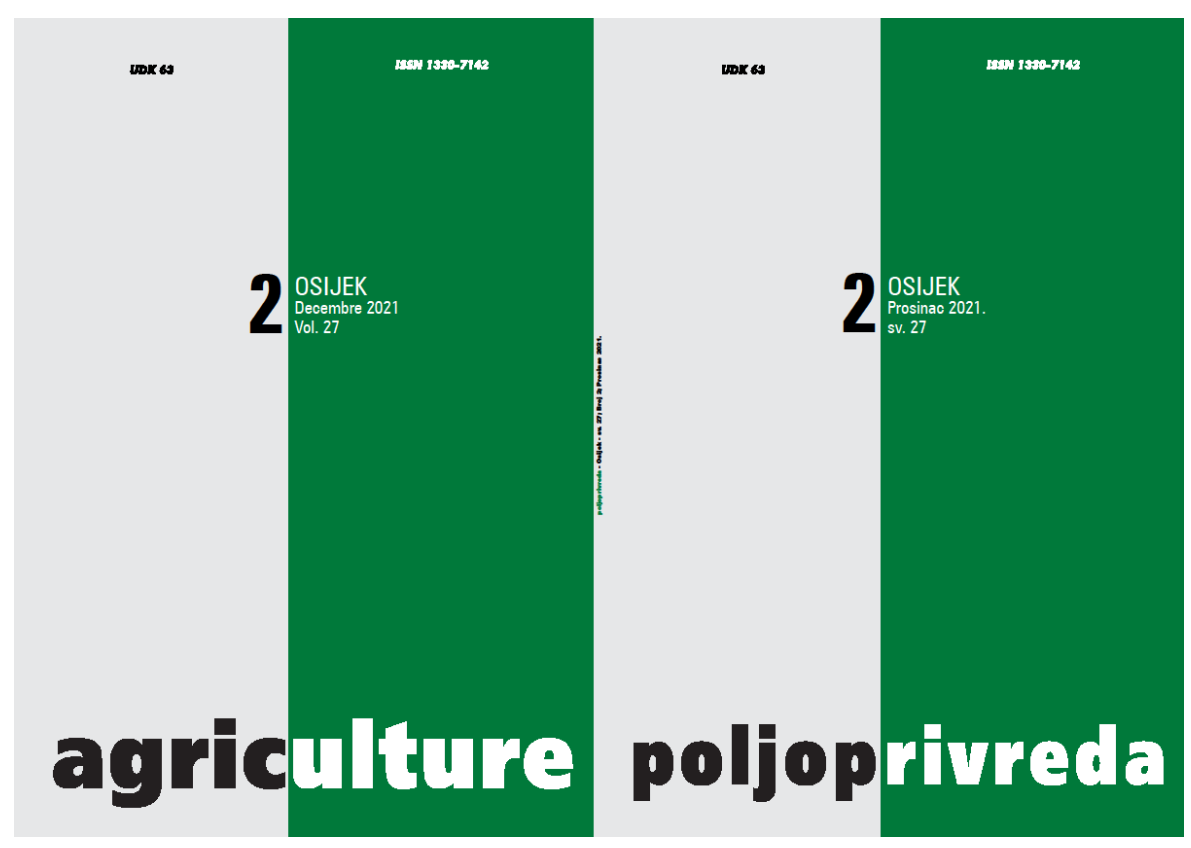

Fakultet agrobiotehničkih znanosti Osijek, Poljoprivredni institut Osijek

Faculty of Agrobiotechnical Sciences Osijek, Agricultural Institute Osijek 


\title{
WEED CONTROL IN SUNFLOWER (Helianthus annuus L.) WITH SOIL-APPLIED HERBICIDES AFFECTED BY A PROLONGED AND LIMITED RAINFALL
}

Pacanoski, Z. ${ }^{(1)}$,Mehmeti, A. ${ }^{(2)}$

Original scientific paper

Izvorni znanstveni članak

\begin{abstract}
SUMMARY
The field trials were carried out in the Bitola and Titov Veles regions during two sunflower growing seasons (2018 and 2019) to estimate a weed control in sunflower with the soil-applied herbicides, influenced by a prolonged and limited rainfall. Polygonum aviculare $L$., Solanum nigrum $L$., Chenopodium album $L$., Amaranthus retroflexus $L$., Portulaca oleracea $L$., and Echinochloa crus-galli $(L)$.$P . Beauv. were$ the most dominant weeds in both regions. The efficacy of PRE-em herbicides varied among the weed species, treatments, periods of efficacy estimation, regions, and years. The overall performances of the PRE-em herbicides were correlated with weather and soil conditions. The inconsistent weather patterns between the two years of the study likely influenced the weed control. All weeds in 2018 in the Bitola region were poorly controlled $(<77 \%$ and $<62 \%, 28$ and 56 days after application, respectively) due to a higher amount of rainfall $(57 \mathrm{~mm})$ during the 10 days of the 1st decade after herbicide application. The herbicide efficacy has only produced a marginal control of weeds in 2019 in the Titov Veles region as well ( $<68 \%$ and $<59 \%$, 28 and 56 days after application, respectively), due to the drought conditions observed in this region in early spring and in mid-spring. A PREem application followed by a heavy rainfall resulted in a sunflower injury in the Bitola region in 2018, ranging from 9 to $28 \%$ across the PRE-em treatments seven days after emergence. The injuries by oxyfluorfen and dimethenamid-P were more serious (24 and $28 \%$, respectively). The sunflower achene yields for each treatment in both regions generally reflected an overall weed control and crop injury.
\end{abstract}

Keywords: PRE-em herbicides, sunflower, weeds

\section{INTRODUCTION}

Weed-crop competition is a major factor limiting worldwide production of many crops, including sunflower. Weed competition has long been known to decrease sunflower yield (Johnson, 1971), because sunflower is usually planted in rows spaced $76 \mathrm{~cm}$ apart at lower densities than many other crops. Weeds cause a $26-83 \%$ reduction in seed yield of sunflower during the entire crop growth season (Khan et al., 1988; Legha et al., 1992; Wanjari et al., 2000; Reddy et al., 2008; Lewis and Gulden, 2014; Lewis et al., 2016). Therefore, weed control during the first few weeks after sunflower sowing is essential for successful yield (Wanjari et al., 2000). Due to its sowing period (mid-March to mid-April), this crop is very often characterized by a complex weed flora, composed of annual spring grass and broad-leaved weeds (Fried et al., 2006). This weed complex has been traditionally controlled with PRE-em herbicide applications, due to a scarce availability of POST-em herbicides (Rapparini, 1996).

A few soil-applied PRE-em herbicides are currently registered for use in sunflower in R. N. Macedonia. Pendimethalin is a dinitroaniline selective herbicide that controls mainly annual grasses (Echinochloa crus-galli (L.) P. Beauv., Setaria spp., Digitaria sanguinalis (L.) Scop.), and some annual broadleaf weeds (Amaranthus retroflexus L., Chenopodium album L.) in corn, cotton, soybeans, potato, sunflower, and several vegetable

(1) Prof. Dr. Zvonko Pacanoski - Ss. Cyril and Methodius University, Faculty of Agricultural Sciences and Food, Goce Delčev Blvd. 9, 1000, Skopje, Republic of North Macedonia, (2) Prof. Dr. Arben Mehmeti (arben.mehmeti@uni-pr.edu) - University of Pristina, Department of Plant Protection, Clinton St., p. n. 10000, Pristina, Republic of Kosovo 
crops (Hatzinikolaou et al., 2004; Lin et al., 2007; Soltani et al., 2015; Naddasi et al. 2008). Metobromuron is a substituted urea herbicide commonly used to control annual broadleaf weeds $(C$. album, $A$. retroflexus, Polygonum spp.) in common bean, soybean, potato, and sunflower. It also controls some annual grasses such as Setaria spp. It is absorbed through the plant roots and translocated in the transpiration stream to the leaves where interferes with photosynthesis (El-Afifi and Lang, 1981; Park and Hamill 1993). Aclonifen and oxyfluorfen belong to the diphenyl ether herbicide group with a photo dependent capability to inhibit protoporphyrinogen oxidase (Grasset et al. 2011; Choi et al. 1999). They are used frequently in soybeans, corn, sunflower, tomatoes, and various other crops against broadleaved $(C$. album, $A$. retroflexus) and some grass weeds (E. crus-galli, Setaria spp.) (Kilinc et al., 2009; Vischetti et al., 2002; Trevisan et al. 1999). S-metolachlor and dimethenamid, both chloroacetamide herbicides, inhibit biosynthesis of fatty acids, lipids, proteins, isoprenoids, and flavonoids (Vencill, 2002). They are primarily absorbed by shoots of grasses as they grow through treated soil. In dicotyledonous plants, root absorption can also be very important in herbicide uptake (Le Baron et al., 1988). $S$-metolachlor and dimethenamid control annual grasses Setaria spp., D. sanguinalis, E. crus-galli, Cyperus esculentus, and some small-seeded broadleaf weeds, including Amaranthus spp. and Solanum spp. (Moseley and Hagood 1990; Osborneet al., 1995; Anonymous,
2000; Clewis et al., 2007). They are registered for use in many crops, including sunflower (Anonymous, 2000). PRE-em herbicides are intended to be applied to the soil, and many require activation by rainfall and irrigation (Rainbow and Derpsch, 2011; Haskins, 2012). It is widely known that PRE-em herbicides, such as $S$-metolachlor and dimethenamid- $P$, require rainfall within 7-10 days after application for proper movement into the active zone of weed seed germination (Steckel et al., 2002; Anonymous, 2008). Taking into consideration the information above, the main objectives of the study were (i) to estimate efficacy of soil applied herbicides in sunflower influenced by high and limited amount of rainfalls, and (ii) to evaluate their injury effect and (iii) influence on the sunflower yield.

\section{MATERIAL AND METHODS}

The field trials were conducted during two sunflower growing seasons in 2018 and 2019 on commercial sunflower fields in the Bitola and Titov Veles sunflower growing regions in south-western and central Macedonia. The soil at the Bitola region was a fluvisol sandy loam with $31.10 \%$ coarse, $50.30 \%$ fine sand, $18.60 \%$ clay + silt, $1.56 \%$ organic matter and $\mathrm{pH}$ of 6.1 . The soil at the Titov Veles region was a vertisol with $3.50 \%$ coarse, $34.20 \%$ sand, $60.3 \%$ silt + clay, $2.4 \%$ organic matter and pH of 7.2 (Filipovski, 2006).

Table 1. Basic data of applied herbicides.

Tablica 1. Osnovni podatci primijenjenih herbicida.

\begin{tabular}{|c|c|c|c|c|}
\hline Treatments / Tretmani & $\begin{array}{c}\text { Content of a. i. / } \\
\text { Sadržaj aktivne tvari (g/l) }\end{array}$ & $\begin{array}{l}\text { Trade name / } \\
\text { Trgovačko ime }\end{array}$ & $\begin{array}{c}\text { Application rate / } \\
\text { Primjenena doza (g. a. i. / ha) }\end{array}$ & $\begin{array}{l}\text { Supplier / } \\
\text { Dobavljač }\end{array}$ \\
\hline $\begin{array}{l}\text { Untreated control / } \\
\text { Netretirana kontrola }\end{array}$ & ------ & ------ & ------ & ------- \\
\hline $\begin{array}{l}\text { Weed-free control / } \\
\text { Beskorovna kontrola }\end{array}$ & ------ & ------ & ------- & ------- \\
\hline Pendimethalin & $455 \mathrm{~g} / \mathrm{l}$ & Stomp Aqua & 1365 & BASF Agro B.V, Switzerland \\
\hline Metobromuron & $500 \mathrm{~g} / \mathrm{l}$ & Proman & 1500 & Belchim Crop Protection, Belgium \\
\hline Oxyfluorfen & $240 \mathrm{~g} / \mathrm{l}$ & Goal & 300 & Dow AgroScience, Indianapolis \\
\hline Aclonifen & $600 \mathrm{~g} / \mathrm{l}$ & Challenge600 EC & 2400 & Bayer Crop Science, Germany \\
\hline S-Metolachlor & $960 \mathrm{~g} / \mathrm{l}$ & Dual Gold 960 & 1440 & Syngenta International, Switzerland \\
\hline Dimethenamid-P & $900 \mathrm{~g} / \mathrm{l}$ & Frontier $900 \mathrm{EC}$ & 1530 & BASF, Germany \\
\hline
\end{tabular}

The sunflower was grown following conventional tillage practices. The seedbed was prepared by moldboard plowing in the autumn followed by two passes with a field cultivator in the spring prior to sowing. Before seeding in the spring, fertilizer was incorporated at rates indicated by soil tests. The field trials were carried out with "Surimi CL" and "Driver CL" sunflower hybrids sowed in a wellprepared soil at a seeding rate of 60,000 seeds/ha and 58,000 seeds/ha on 17 April 2018 and 11 April 2019 in the Bitola region, and on 8 April 2018 and 3 April 2019 in the Titov Veles region. The trials were conducted in two different sites of the same commercial sunflower fields. Herbicides were applied with a $\mathrm{CO}_{2}$-pressurized backpack sprayer calibrated to deliver $300 \mathrm{I} /$ ha aqueous solution at $220 \mathrm{kPa}$. Herbicides were applied on 20 April 2018 and 14 April 2019 in the Bitola region, and on 12 April 2018 and 7 April 2019 in the Titov Veles region. Weeds at the time of treatment were in the same growth stages as sunflower (BBCH 00-01). The experimental design was a randomized complete block with four replicates (Table 1).

Untreated and weed-free controls were included in the studies, as well. The weedy control plots were left untreated during the entire experimental period. Weed-free control was maintained by hand weeding. Hand weeding was initiated at weed emergence and 
continued as needed to maintain weed-free plots. Weed control efficacy was estimated 28 days after applications (DAAs) shortly after weed emergence (four true sunflower leaves, BBCH 14; the first assessment), and 56 DAAs shortly before canopy closure (BBCH 30-32; the second assessment) by counting the weed plants in a $1 \mathrm{~m}^{2}$ area within each plot. Herbicide efficacy was calculated by equitation (Chinnusamy et al., 2013):

$$
W_{\text {CE }}=\frac{\text { Wup }- \text { Wtp }}{\text { Wup }} \times 100
$$

where:

$W_{C E}-$ weed control efficiency
Wup - number of weeds in the untreated plots

Wtp - number of weeds in the treated plots

Sunflower injury was visually evaluated based on a $0-100 \%$ rating scale, where 0 is no injury to sunflower plants and 100 is a complete death of sunflower plants (Franset al., 1986). Visual estimates of percent sunflower injury were performed seven and 21 days after emergence (DAE), based on chlorosis and necrosis for each plot at both localities during two-year experimental period. The yield was determined after harvest, based on weights of achene containing $9 \%$ moisture.

Table 2. Temperatures (T) and rainfall (P) data 10 DAAs in the Bitola and Titov Veles regions in 2018 and 2019.

Tablica 2. Podatci o temperaturama (T) i padalinama (P) 10 DAA u regiji Bitolj i Titov Veles u 2018. i 2019. godini.

\begin{tabular}{|c|c|c|c|c|c|c|c|c|c|}
\hline \multirow{3}{*}{ Date /Datum } & \multicolumn{4}{|c|}{ Bitola region / Regija Bitolj } & \multirow{3}{*}{ Date / Datum } & \multicolumn{4}{|c|}{ Titov Veles region / Regija Titov Veles } \\
\hline & \multicolumn{2}{|c|}{2018} & \multicolumn{2}{|c|}{2019} & & \multicolumn{2}{|c|}{2018} & \multicolumn{2}{|c|}{2019} \\
\hline & $P(\mathrm{~mm})$ & $\mathrm{T}\left({ }^{\circ} \mathrm{C}\right)$ & $P(\mathrm{~mm})$ & $\mathrm{T}\left({ }^{\circ} \mathrm{C}\right)$ & & $P(\mathrm{~mm})$ & $\mathrm{T}\left({ }^{\circ} \mathrm{C}\right)$ & $P(\mathrm{~mm})$ & $\mathrm{T}\left({ }^{\circ} \mathrm{C}\right)$ \\
\hline April 12 & - & - & 5 & 11 & April 4 & - & - & 0 & 14 \\
\hline April 13 & - & - & 4 & 14 & April 5 & - & - & 0 & 16 \\
\hline April 14 & - & - & 0 & 14 & April 6 & - & - & 0 & 15 \\
\hline April 15 & - & - & 6 & 11 & April 7 & - & - & 3 & 12 \\
\hline April 16 & - & - & 0 & 15 & April 8 & - & - & 4 & 16 \\
\hline April 17 & - & - & 7 & 9 & April 9 & 0 & 13 & 0 & 12 \\
\hline April 18 & 2 & 12 & 0 & 14 & April 10 & 7 & 10 & 0 & 15 \\
\hline April 19 & 13 & 7 & 5 & 12 & April 11 & 5 & 11 & 0 & 16 \\
\hline April 20 & 14 & 8 & 3 & 12 & April 12 & 4 & 9 & 0 & 14 \\
\hline April 21 & 3 & 10 & 0 & 14 & April 13 & 0 & 11 & 5 & 15 \\
\hline April 22 & 12 & 10 & - & - & April 14 & 5 & 10 & - & - \\
\hline April 23 & 0 & 7 & - & - & April 15 & 0 & 12 & - & - \\
\hline April 24 & 0 & 9 & - & - & April 16 & 0 & 12 & - & - \\
\hline April 25 & 7 & 10 & & & April 17 & 7 & 10 & - & - \\
\hline April 26 & 6 & 10 & & & April 18 & 0 & 14 & - & - \\
\hline April 27 & 0 & 12 & & & & & & & \\
\hline
\end{tabular}

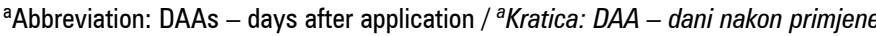

Total rainfall, as well as average temperatures 10 DAAs, were recorded (Table 2). In 2018, the first few DAAs in the Bitola region were unusually wet, particularly the 2nd, 3rd, and 5th day $(13,14$ and $12 \mathrm{~mm}$, respectively). In the Titov Veles region for the same year, the rainfall that occurred in the first 10 days of application was a little above the 30 -year average for this region $(38 \mathrm{~mm})$. In 2019, rainfall occurring in the first 10 days of application was scarce in the Bitola region, while the Titov Veles region was very dry $(12 \mathrm{~mm})$ in the same year and period during the 10 DAAs. In Titov Veles region it rained on the 4th, 5th, and 10th days (Table 2). The 10 DAA temperatures, particularly in 2019 , for both regions were a little bit above the 30-year average (12.6 and $14.5^{\circ} \mathrm{C}$ ). That was attributed to the favorable environmental conditions associated with the non-frost night times during the estimated 10-day period after PRE-em applications. The PRE-em treatments in both years were applied at times when herbicide applications typically occur in North Macedonia sunflower production and are thus representative of producer practices and label recommendations.

The data were tested for homogeneity of variance and normality of distribution (Ramsey and Schafer, 1997) and were log-transformed, as needed, to obtain roughly equal variances and better symmetry before ANOVA were performed. Data were transformed back to their original scale for presentation. Means were separated by using LSD test at $5 \%$ of probability.

\section{RESULTS AND DISCUSSION}

\section{Weed population}

The weed population in both regions for both years consisted of annual spring and summer weeds. In the Bitola region in both years, the weed populations con- 
sisted of nine and eight weed species, and total number of weeds in the non-treated control plot was 127 and 88 plants $/ \mathrm{m}^{2}$ in 2018 and 2019, respectively (Table 2). The most prevalent weed species for both years were Polygonum aviculare L., Solanum nigrum L., Ch. album L., A. retroflexus L., Portulaca oleracea L., and
E. crus-galli (L.) P. Beauv. The weediness in the Titov Veles region was higher, with a total number of weeds in non-treated control plot at 212 and 125 plants $/ \mathrm{m}^{2}$ in 2018 and 2019, respectively. The most prevalent weed species were $A$. retroflexus L., Ch. album L., P. oleracea $\mathrm{L}$, and $S$. nigrum L. (Table 3).

Table 3. Weed population (species and number of weeds) in sunflower at Bitola and Titov Veles region in 2018 and 2019. Tablica 3. Populacija korova (vrste i broj korova) u suncokretu u regiji Bitolj i Titov Veles u 2018. i 2019. godini.

\begin{tabular}{|c|c|c|c|c|}
\hline \multirow[t]{2}{*}{$\begin{array}{c}\text { Weed species / } \\
\text { Vrste korova }\end{array}$} & \multicolumn{2}{|c|}{$\begin{array}{l}\text { Bitola region / } \\
\text { Regija Bitolj }\end{array}$} & \multicolumn{2}{|c|}{$\begin{array}{l}\text { Titov Veles region / } \\
\text { Regija Titov Veles }\end{array}$} \\
\hline & 2018 & 2019 & 2018 & 2019 \\
\hline Polygonum aviculare L. & 33 & 14 & - & - \\
\hline Chenopodium album $\mathrm{L}$. & 24 & 21 & 54 & 27 \\
\hline Solanum nigrum $\mathrm{L}$. & 27 & 13 & 38 & 16 \\
\hline Amaranthus retroflexus $\mathrm{L}$. & 18 & 17 & 66 & 40 \\
\hline Echinochloa crus-galli (L.) P. Beauv. & 16 & 14 & - & - \\
\hline Galinsoga parviflora Cav. & 4 & 2 & - & - \\
\hline Abutilon theophrasti Medic. & 2 & 3 & 2 & 1 \\
\hline Diplotaxis muralis (L.) D.C. & 2 & - & 3 & 3 \\
\hline Portulaca oleracea L. & 1 & 4 & 48 & 29 \\
\hline Digitaria sanguinalis (L.) Scop. & - & - & & 9 \\
\hline Total weed species / Ukupno vrsta korova & 9 & 8 & 6 & 7 \\
\hline Total weeds $\left(\mathrm{No} / \mathrm{m}^{2}\right)$ / Ukupno korova $\left(\mathrm{br} . / \mathrm{m}^{2}\right)$ & 127 & 88 & 212 & 125 \\
\hline
\end{tabular}

\section{Weed control}

Efficacy of PRE-em herbicides varied among weed species, treatments, periods of efficacy estimation, regions and years. Overall performance of the PRE-em herbicides was correlated with the weather and soil conditions. Inconsistent weather patterns between the two years of study likely influenced weed control. The humid April in 2018 (Table 2), particularly first 10 days after PRE-em application (57 mm), most likely caused the leaching of herbicides from soil surface and the lower efficacy of PRE-em applied herbicides in 2018 compared to their application in 2019 in the Bitola region (Table 4). Usually, higher amounts of rainfall and heavy rains immediately after PRE-em application, particularly on sandy soils with low organic matter (Inoue et al., 2010; WSSA, 2014), may cause leaching of herbicides through the soil profile below the weed seed-germinating zone and consequently decrease weed control efficacy (Heatherly and Hodges, 1999; Ferrell et al., 2004). Additionally, depending on soil type, high amounts of rainfall (i.e., greater than $25 \mathrm{~mm}$ ), especially immediately after application, can cause herbicides to leach through the soil profile and consequently reduce efficacy and increase sunflower crop injury (Reddy and Locke, 1996; Ferrell et al., 2004; Boerboom et al., 2006). Furthermore, inadequate or delayed rainfall can reduce herbicide effectiveness and decrease weed control (Armel et al., 2003; Lyon and Wilson, 2005; Loux et al., 2008). Nevertheless, Jursík et al., (2013) reported that selectivity of S-metolachlor for sunflower was not affected by natural precipitation or irrigation, although S-metolachlor leaching in soil is relatively high. In 2018 , rainfall slightly above the 30 -year average was recorded in Titov Veles, but due to their even occurrence throughout the first 10 DAAs, as well as soil type characteristics (higher content of clay and organic) leaching did not occur, and efficacy was satisfactory. However, the limited rainfall in 2019 after PRE-em application 10 DAAs may have contributed to the inferior performance of PRE-em herbicides in Titov Veles region compared with 2018 (Table 5). Since many of the PREem herbicides can volatilize and photodegrade on the soil surface over time, rainfall is needed to move these herbicides into the zone where weed seeds germinate (Wilcut et al., 1994; Janak and Grichar, 2016), which explains the inconsistent control of predominant weeds noted with PRE-em herbicides under the drought conditions observed in the Titov Veles region in early and midspring 2019. It is reported that the efficacy of PRE-em herbicides is expressively affected by soil moisture, with the efficacy of PRE-em herbicides generally decreasing in dry conditions (Zanatta et al., 2008) and crop injury increasing after use of PRE-em herbicides with higher amounts of precipitation (Soukup et al., 2004).

However, in both regions, regardless of year and herbicide treatments, efficacy of PRE-em herbicides was lower 56 DAAs due to new weed emergence occurring between two estimation periods. It was significantly lower only in the Bitola region in 2018 (Table 4 and 5).

In 2018, PRE-em herbicides provided no more than $74 \%$ and $59 \%$ control of $P$. aviculare, 28 and 56 DAAs, respectively, while the control of $P$. aviculare was significantly improved in 2019. During the first estimation period (28 DAAs), P. aviculare was nearly fully controlled $(>98 \%)$ while there was an insignificant decrease in effi- 
cacy to $94 \%$ (dimethenamid) and $98 \%$ (pendimethalin) for PRE-em herbicides provided 56 DAAs (Table 4). In black locust (Robinia pseudoacacia L.) nurseries in 2010, S-metolachlor and pendimethalin controlled $P$. aviculare $\geq 90 \%, 28$ DATs and 56 DAAs, respectively. Lower herbicide efficacy was noticed in 2011 (between 75 and 83\%) most likely due to high rainfall occurring immediately after herbicide application (Pacanoski et al., 2016).

The control of $S$. nigrum significantly differed among periods of efficacy estimation only in 2018 in the Bitola region with overall PRE-em herbicides providing poor control of $S$. nigrum. Nevertheless, the 28 DAA efficacy ranged between $64 \%$ (aclonifen) and $77 \%$ (dimethenamid-P). Significantly lower efficacy from $49 \%$ (metobromuron) to $62 \%$ (dimethenamid and oxyfluorfen) was recorded subsequent to 56 DAAs (Table 4). The $S$. nigrum control was substantially improved in 2019 (Table 4). Unlike the Bitola region, in the Titov Veles region PRE-em herbicides provided significantly higher control of $S$. nigrum in 2018. Oxyfluorfen provided control of $96 \%$, pendimethalin and dimethenamid-P $94 \%$, and S-metolachlor $93 \%$, while aclonifen and metobromuron controlled S. nigrum only 70 and $73 \%$, i.e., 28 DAAs. However, in 2019, due to dry soil conditions, the control of $S$. nigrum was less than $64 \%$ and $60 \%$, in 28 and 56 DAAs, respectively (Table 5). Pendimethalin, $S$-metolachlor, and dimethenamid-P showed high selectivity to transplanted tomatoes with effective control of S. nigrum (Frost and Barnes, 2003). Similarly, according to Pannacci and Onofri (2016), S-metolachlor had the $S$. nigrum control of about $100 \%, 60$ days after maize crop emergence. In the field trials conducted from 2009 until 2012, Bergmann (2016) concluded that Proman (metobromuron) applied at $3 \mathrm{l} / \mathrm{ha}$ provided only $70 \%$ control of $S$. nigrum. Similarly, in the investigation by Pannacci et al. (2007), aclonifen applied at $900 \mathrm{~g}$ a. i. ha ${ }^{-1}$ provided poor control of $S$. nigrum (33-67\%).

The Ch. album weed control significantly differed among periods of efficacy estimation only in 2018 in the Bitola region, with all investigated herbicides providing inadequate control of $\mathrm{Ch}$. album at 28 DAA efficacies ranging between $56 \%$ (dimethenamid) and $67 \%$ (oxyfluorfen). These further significantly decreased in efficacy, from $37 \%$ (metobromuron) to $48 \%$ (pendimethalin), in 56 DAAs. The control of Ch. album was significantly increased in 2019. The herbicide oxyfluorfen in 28 DAAs fully controlled Ch. album (100\%), while the rest of the herbicides controlled this weed between 95 and $98 \%$. All PRE-em herbicides provided effective Ch. album control in the Titov Veles region in 2018. During the first estimation period (28 DAA), Ch. album was controlled between $90 \%$ (S-metolachlor) and 96\% (metobromuron). Ch. album control was lower, although insignificantly, at $81 \%$ (dimethenamid-P) and $89 \%$ (pendimethalin) for the herbicides provided in 56 DAAs. Contrary, due to dry soil conditions in 2019, control of Ch. album was less than $64 \%$ and $55 \%$, in 28 and 56 DAAs, respectively (Table 5). In a banded herbicide application in a conventional sunflower production system, aclonifen applied at $0.75 \mathrm{~kg}$ a. i. ha ${ }^{-1}$ controlled Ch. album between 84 and $89 \%$ (Serim et al., 2018). In the study of Jursík et al. (2015), acloni- fen controlled Ch. album with an efficacy greater than $97 \%$, regardless of irrigation, but oxyfluorfen was not as effective on Ch. album under non-irrigated conditions. Oxyfluorfen applied at 240 a. i. ha in sunflower controlled Ch. album 100\% (Pannacci et al., 2007), as did aclonifen at 900 a. i. ha ${ }^{-1}$ in sorghum (Pannacci and Bartolini, 2018). Similarly, in the banana pepper, S-metolachlor applied at $534 \mathrm{~g}$ a. i. ha ${ }^{-1}$ provided $99 \%$ control of $\mathrm{Ch}$. album two weeks after treatment (WAT) and $85 \%$ in four WATs, while S-metolachlor applied at $1070 \mathrm{~g} \mathrm{a}$. i. ha ${ }^{-1}$ provided $96 \%$ control of Ch. album two WATs and $90 \%$ in four WATs (Mohseni-Moghadam and Doohan, 2015).

In the Bitola region in 2018 , A. retroflexus was controlled between 60 and $46 \%$ (dimethenamid-P) and 73 and $52 \%$ (oxyfluorfen), in 28 and 56 DAAs, respectively. Herbicides provided a significantly increased control of A. retroflexus in 2019. In fact, in 28 DAAs, metobromuron fully controlled $A$. retroflexus $(100 \%)$, and the rest of the herbicides provided control of this weed between 94 and $98 \%$ (Table 4). In 2018 in the Titov Veles region, the PRE-em herbicides effectively controlled $A$. retroflexus $(>93 \%$ and $>85 \%)$, in 28 and 56 DAAs, respectively. In 2019, PRE-em herbicides' efficacy substantially decreased with only marginal control of $A$. retroflexus $(<68 \%$ and $<61 \%)$, in 28 and 56 DAAs, respectively (Table 5). S-metolachlor in the irrigated sunflower plots completely controlled $A$. retroflexus (efficacy $100 \%$ ), while aclonifen controlled $A$. retroflexus with an efficacy greater than $97 \%$, regardless of irrigation, as well as oxyfluorfen which provided control greater than $95 \%$. However, in a treatment without irrigation, the efficacy of $\mathrm{S}$-metolachlor on $A$. retroflexus decreased by $8 \%$ (Jursík et al., 2015). In the investigation of Pannacci et al. (2007), pendimethalin applied at $921 \mathrm{~g} \mathrm{a}$. i. ha in sunflower controlled $A$. retroflexus between $88 \%$ and $100 \%$. Dimethenamid- $P$ applied alone gave excellent control $(>98 \%)$ of $A$. retroflexus in dry bean (Arnold et al., 2012). An evaluation of PRE herbicides for weed control in pumpkin found that 21 days after treatment dimethenamid applied at $2.24 \mathrm{~kg} \mathrm{ha}^{-1}$ resulted in $81-100 \%$ control of $A$. retroflexus (Brown and Masiunas, 2002). Similarly, in sugar beet crop, dimethenamid-P applied at $0.84 \mathrm{~kg}$ ha $^{-1}$ and S-metolachlor at $1.4 \mathrm{~kg} \mathrm{ha}^{-1}$ controlled $A$. retroflexus $>98 \%$ (Bollman and Sprague, 2007). However, the efficacy of pendimethalin on $A$. retroflexus was affected by irrigation (Pannacci et al., 2007).

The PRE-em herbicides provided poor control of $E$. crus-galli in 2018. The efficacy was between $55 \%$ and $39 \%$ (metobromuron), and $70 \%$ and $52 \%$ (S-metolachlor) in 28 and 56 DAAs, respectively. However, the control of $E$. crus-galli was significantly improved in 2019. The herbicides S-metolachlor and dimethenamid in 28 DAAs fully controlled $E$. crus-galli $(100 \%)$, while the rest of the herbicides, except metobromuron, controlled this weed between 96 and $98 \%$. The control of $E$. crus-galli control insignificantly decreased in 56 DAAs. Except metobromuron which controlled E. crus-galli only $75 \%$, the rest of the PRE-em herbicides provided control of this weed between 88 and $93 \%$ (Table 4). Similar results were reported by Bergmann (2016) in field trials conducted from 2009 until 2012, who concluded that 
Proman (metobromuron) applied at $3 \mathrm{I} \mathrm{ha}^{-1}$ provided only $63 \%$ control on $E$. crus-galli. S-metolachlor in irrigated sunflower plots nearly completely controlled $E$. crus-galli (efficacy 93-100\%). However, in treatment without irrigation, the efficacy of S-metolachlor on $E$. crus-galli decreased significantly by $13 \%$ (Jursík et al., 2015). In the same study, efficacy of pendimethalin $E$. crus-galli ranged between $85-98 \%$. In the investigation by Pannacci et al. (2007), pendimethalin applied at 921 $\mathrm{g}$ a. i. ha ${ }^{-1}$ in sunflower controlled $E$. crus-galli between 94-100\%.

The control of $P$. oleracea did not differ among periods of efficacy estimation by year. In 2018, during the first estimation period (28 DAA), dimethenamid$P$ and S-metolachlor controlled $P$. oleracea between
$85-88 \%$, while the other herbicides provided control $>90 \%$. During the second estimation period (56 DAA), all investigated PRE-em herbicides provided control of $P$. oleracea $>80 \%$, except S-metolachlor. In 2019, efficacy of PRE-em herbicides substantially decreased. Herbicides gave only marginal control of $P$. oleracea $(<68 \%$ and $<57 \%$, 28 and 56 DAA, respectively) (Table 5). In banana pepper, S-metolachlor applied at $534 \mathrm{~g}$ a. i. $\mathrm{ha}^{-1}$ and $1070 \mathrm{~g} \mathrm{a}$. i. ha ${ }^{-1}$ provided control of $P$. oleracea between 61 and $67 \%$ (Mohseni-Moghadam and Doohan, 2015). Aclonifen gave good total weed control, with values of efficacy between $81-88 \%$ due to good efficacy against $P$. oleracea, the main species in the sorghum crop (Pannacci and Bartolini, 2018).

Table 4. Polygonum aviculare, Solanum nigrum, Chenopodium album, Amaranthus retroflexus, and Echinochloa crusgalli control (\%) 28 and 56 days after PRE-em herbicide applications in sunflower in 2018 and 2019 in Bitola region

Tablica 4. Polygonum aviculare, Solanum nigrum, Chenopodium album, Amaranthus retroflexus $i$ Echinochloa crus-galli, kontrola (\%) 28 i 56 dana nakon PRE-em primjene herbicida u suncokretu 2018. i 2019. u Bitolju.

\begin{tabular}{|c|c|c|c|c|c|c|c|c|c|c|c|c|c|c|c|c|c|c|c|c|c|}
\hline \multirow{4}{*}{$\begin{array}{l}\text { Treatments / } \\
\text { Tretmani }\end{array}$} & \multirow{4}{*}{$\begin{array}{l}\text { Rate (g } \\
\text { a. i./ha) / } \\
\text { Doza (g } \\
\text { aktivne } \\
\text { tvari /ha) }\end{array}$} & \multicolumn{20}{|c|}{ Bitola region / Regija Bitolj } \\
\hline & & \multicolumn{4}{|c|}{ P. aviculare } & \multicolumn{4}{|c|}{ S. nigrum } & \multicolumn{4}{|c|}{ Ch. album } & \multicolumn{4}{|c|}{ A. retroflexus } & \multicolumn{4}{|c|}{ E. crus-galli } \\
\hline & & \multicolumn{2}{|c|}{2018} & \multicolumn{2}{|c|}{2019} & \multicolumn{2}{|c|}{2018} & \multicolumn{2}{|c|}{2019} & \multicolumn{2}{|c|}{2018} & \multicolumn{2}{|c|}{2019} & \multicolumn{2}{|c|}{2018} & \multicolumn{2}{|c|}{2019} & \multicolumn{2}{|c|}{2018} & \multicolumn{2}{|c|}{2019} \\
\hline & & $\begin{array}{c}28 \\
\text { DAAs }\end{array}$ & 56 & $\begin{array}{c}28 \\
\text { DAAs }\end{array}$ & $\begin{array}{c}56 \\
\text { DAAs }\end{array}$ & $\begin{array}{c}28 \\
D A A s\end{array}$ & $\begin{array}{c}56 \\
\text { DAAs }\end{array}$ & $\begin{array}{c}28 \\
\mathrm{DAAs}\end{array}$ & $\begin{array}{c}56 \\
\text { DAAs }\end{array}$ & $\begin{array}{c}28 \\
\text { DAAs }\end{array}$ & $\begin{array}{c}56 \\
\text { DAAs }\end{array}$ & $\begin{array}{c}28 \\
\text { DAAs }\end{array}$ & $\begin{array}{c}56 \\
D A A s\end{array}$ & 28 & $\begin{array}{c}56 \\
\text { DAAs }\end{array}$ & $\begin{array}{c}28 \\
\text { DAAs }\end{array}$ & $\begin{array}{c}56 \\
\text { DAAs }\end{array}$ & $\begin{array}{c}28 \\
\text { DAAs }\end{array}$ & 56 & 28 & $\begin{array}{c}56 \\
\text { DAAs }\end{array}$ \\
\hline $\begin{array}{l}\text { Weedy control } \\
\text { / Zakorovljena } \\
\text { kontrola }\end{array}$ & ----- & 0 & 0 & 0 & 0 & 0 & 0 & 0 & 0 & 0 & 0 & 0 & 0 & 0 & 0 & 0 & 0 & 0 & 0 & 0 & 0 \\
\hline $\begin{array}{l}\text { Pendimethalin } \\
\text { Metobromuron } \\
\text { Oxyfluorfen }\end{array}$ & $\begin{array}{l}1365 \\
1500 \\
300\end{array}$ & $\begin{array}{l}74^{\mathrm{a}} \\
63^{\mathrm{bc}} \\
71^{\mathrm{ab}}\end{array}$ & $\begin{array}{c}59^{\mathrm{a}} \\
51^{\mathrm{ab}} \\
58^{\mathrm{a}}\end{array}$ & $\begin{array}{c}100^{\mathrm{a}} \\
98^{\mathrm{b}} \\
98^{\mathrm{b}}\end{array}$ & $\begin{array}{c}98^{\mathrm{a}} \\
95^{\mathrm{ab}} \\
95^{\mathrm{ab}}\end{array}$ & $\begin{array}{c}75^{\mathrm{a}} \\
68^{\mathrm{bc}} \\
75^{\mathrm{a}}\end{array}$ & $\begin{array}{l}58^{\mathrm{a}} \\
49^{\mathrm{b}} \\
62^{\mathrm{a}}\end{array}$ & $\begin{array}{l}95^{\mathrm{a}} \\
75^{\mathrm{b}} \\
98^{\mathrm{a}}\end{array}$ & $\begin{array}{l}87^{\mathrm{a}} \\
66^{\mathrm{b}} \\
92^{\mathrm{a}}\end{array}$ & $\begin{array}{c}65^{\mathrm{a}} \\
59^{\mathrm{bc}} \\
67^{\mathrm{a}}\end{array}$ & $\begin{array}{l}48^{\mathrm{a}} \\
37^{\mathrm{c}} \\
47^{\mathrm{a}}\end{array}$ & $\left|\begin{array}{c}96^{\mathrm{b}} \\
95^{\mathrm{b}} \\
100^{\mathrm{a}}\end{array}\right|$ & $\begin{array}{l}89^{\mathrm{a}} \\
90^{\mathrm{a}} \\
92^{\mathrm{a}}\end{array}$ & $\begin{array}{l}70^{\mathrm{ab}} \\
65^{\mathrm{bc}} \\
73^{\mathrm{a}}\end{array}$ & $\mid \begin{array}{c}51^{\mathrm{ab}} \\
48^{\mathrm{ab}} \\
52^{\mathrm{a}}\end{array}$ & $\begin{array}{l}97^{\mathrm{bc}} \\
100^{\mathrm{a}} \\
97^{\mathrm{bc}}\end{array}$ & $\begin{array}{l}90^{\mathrm{a}} \\
92^{\mathrm{a}} \\
93^{\mathrm{a}}\end{array}$ & $\begin{array}{l}69^{\mathrm{a}} \\
55^{\mathrm{b}} \\
69^{\mathrm{a}}\end{array}$ & $\begin{array}{c}44^{\mathrm{bc}} \\
39^{\mathrm{c}} \\
47^{\mathrm{ab}}\end{array}$ & $\begin{array}{l}96^{\mathrm{b}} \\
82^{\mathrm{c}} \\
97^{\mathrm{ab}}\end{array}$ & $\begin{array}{c}89^{\mathrm{ab}} \\
75^{\mathrm{c}} \\
88^{\mathrm{ab}}\end{array}$ \\
\hline Aclonifen & 2400 & $68^{\mathrm{abc}}$ & $56^{a}$ & $100^{\mathrm{a}}$ & $97^{\mathrm{ab}}$ & $64^{\mathrm{c}}$ & $50^{c}$ & $73^{b}$ & $63^{b}$ & $64^{\mathrm{ab}}$ & $46^{\mathrm{ab}}$ & $98^{\mathrm{ab}}$ & $91^{\mathrm{a}}$ & $68^{\mathrm{ab}}$ & $51^{\mathrm{ab}}$ & $98^{\mathrm{ab}}$ & $91^{\mathrm{a}}$ & $67^{\mathrm{a}}$ & $47^{\mathrm{ab}}$ & $98^{\mathrm{ab}}$ & $90^{\mathrm{ab}}$ \\
\hline S-metolachlor & 1440 & $65^{\mathrm{bc}}$ & $51^{a b}$ & $99^{\mathrm{ab}}$ & $97^{\mathrm{ab}}$ & $71^{\mathrm{ab}}$ & $55^{\mathrm{b}}$ & $95^{\mathrm{a}}$ & $89^{\mathrm{a}}$ & $61^{\mathrm{ab}}$ & $43^{\mathrm{abc}}$ & $97^{\mathrm{ab}}$ & $92^{\mathrm{a}}$ & $63^{\mathrm{bc}}$ & $48^{\mathrm{ab}}$ & $95^{\text {cd }}$ & $87^{a}$ & $70^{\mathrm{a}}$ & $52^{\mathrm{a}}$ & $100^{\mathrm{a}}$ & $93^{\mathrm{a}}$ \\
\hline Dimethenamid-P & 1530 & $60^{c}$ & $47^{b}$ & $99^{\mathrm{ab}}$ & $94^{\mathrm{b}}$ & $77^{\mathrm{a}}$ & $62^{\mathrm{ab}}$ & $96^{\mathrm{a}}$ & $91^{\mathrm{a}}$ & $56^{c}$ & $39^{\mathrm{bc}}$ & $95^{\mathrm{b}}$ & $88^{\mathrm{a}}$ & $60^{c}$ & $46^{\mathrm{b}}$ & $94^{d}$ & $89^{\mathrm{a}}$ & $64^{\mathrm{a}}$ & $44^{\mathrm{bc}}$ & $100^{\mathrm{a}}$ & $92^{\mathrm{a}}$ \\
\hline LSD 0.05 & & 8.14 & 8.12 & 1.87 & 3.41 & 6.14 & 5.03 & 3.68 & 5.95 & 7.54 & 7.09 & 3.90 & 6.14 & 7.86 & 5.41 & 2.03 & 5.33 & 6.52 & 7.07 & 3.09 & 5.72 \\
\hline $\begin{array}{l}\text { Random effect } \\
\text { interactions PRE- } \\
\text { em herbicides } \\
\text { treatment x year } \\
\text { / Međudjelovanja } \\
\text { slučajnoga učinka } \\
\text { PRE-em tretman } \\
\text { herbicida x god. }\end{array}$ & & & * & * & & & * & $*$ & & & * & & & & & * & & & & * & \\
\hline $\begin{array}{l}\text { PRE-em herbicides } \\
\text { treatment x PEE / } \\
\text { PRE-em herbicidi } \\
\text { tretman x PEE }\end{array}$ & & & * & $\mathrm{N}$ & IS & * & * & NS & IS & * & * & NS & S & * & * & NS & IS & & * & & NS \\
\hline
\end{tabular}

aAbbreviation: PRE-em - preemergence; DAA - days after application; PEE - periods of efficacy estimation; NS - not significant; *significant at the $5 \%$ level according to a Fisher's protected LSD test at $\mathrm{P}<0.05$ / ${ }^{\text {KKratica: }}$ PRE-em - prije nicanja; DAA - dani nakon primjene; PEE - razdoblja procjene djelotvornosti; NS - nije značajno; *značajno na razini od $5 \%$ prema Fisherovu zaštićenom $L S D$ testu pri $P<0,05$

${ }^{b} P R E$ treatments were applied in the same growth stages as sunflower (at dry seed - beginning of seed imbibitions, sunflower growing stage - $(\mathrm{BBCH} 00-01) /{ }^{b} P R E$ tretmani primijenjeni su tijekom istih faza rasta kao kod suncokreta (kod suhoga sjemena - početak imbibicije sjemena, faza suncokretova rasta) - (BBCH 00-01)

${ }^{c}$ Weed control efficacy was estimated within 28 DAAs and 56 DAAs / ${ }^{C}$ Djelotvornost suzbijanja korova procijenjena je 28 i 56 dana nakon primjene / ${ }^{\mathrm{C} N a d z o r}$ suzbijanja korova procijenjen je unutar 28 i 56 dana nakon primjene

${ }^{d}$ Means followed by the same letter within a column are not significantly different according to Fisher's Protected LSD test at $\mathrm{P}<0.05 /{ }^{d}$ Srednje vrijednosti iza kojih slijedi isto slovo unutar stupca nisu značajno različite prema Fisherovu zaštićenom $L S D$ testu pri $P<0,05$ 
Table 5. Amaranthus retroflexus, Chenopodium album, Portulaca oleracea, and Solanum nigrum control (\%) 28 and 56 days after PRE-em herbicide applications in sunflower in 2018 and 2019 in Titov Veles

Tablica 5. Amaranthus retroflexus, Chenopodium album, Portulaca oleracea $i$ Solanum nigrum, kontrola (\%) 28 i 56 dana nakon PRE-em primjene herbicida u suncokretu 2018. i 2019. u Titovu Velesu.

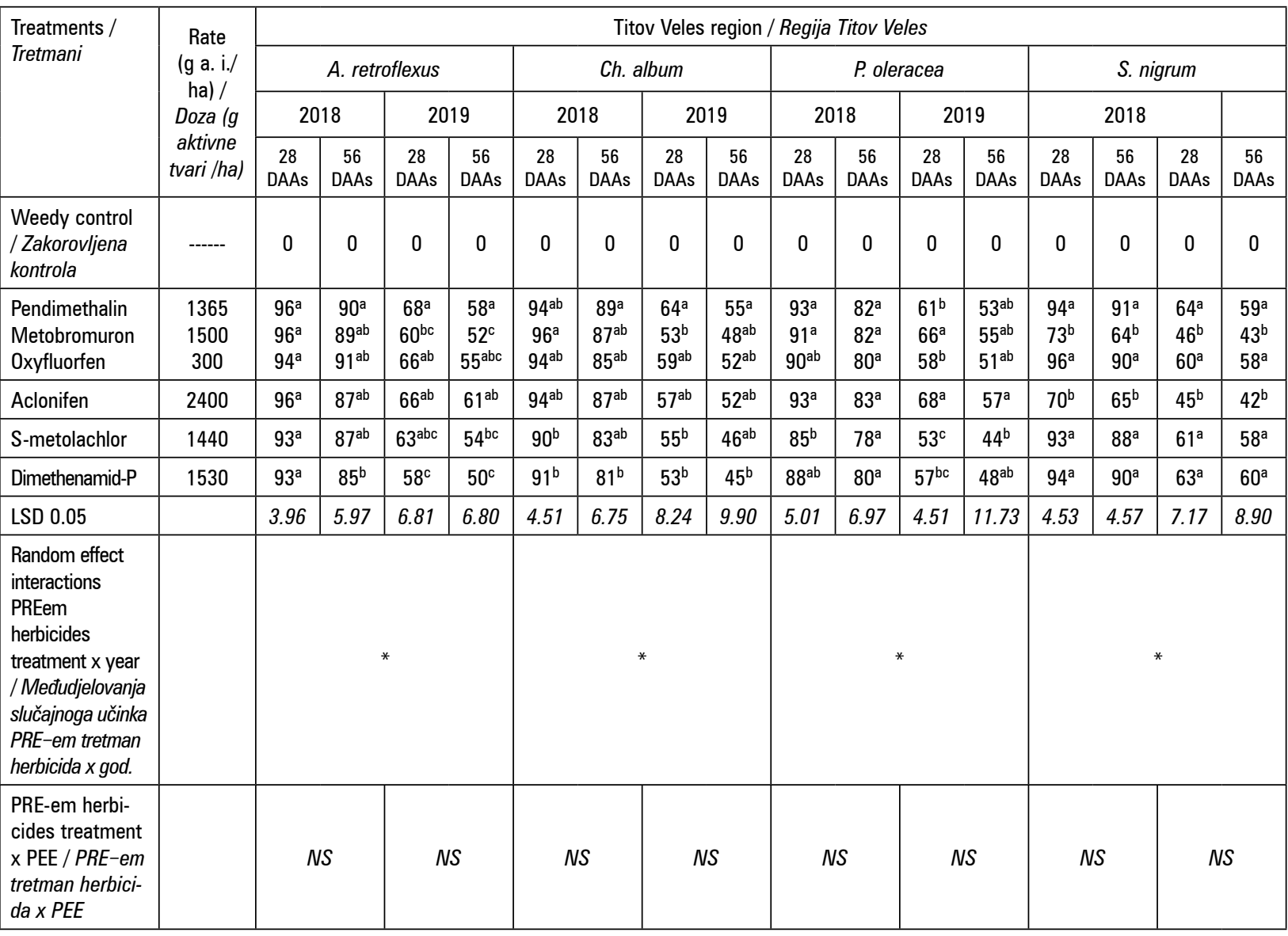

${ }^{a}$ Abbreviations: PRE-em-preemergence; DAA - days after application; PEE-periods of efficacy estimation; NS - not significant; *significant at the $5 \%$ level accord-

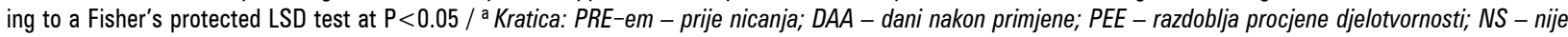
značajno; *značajno na razini od $5 \%$ prema Fisherovu zaštićenom $L S D$ testu pri $P<0,05$

bPRE treatments were applied in the same growth stages as sunflower (at dry seed - beginning of seed imbibitions, sunflower growing stage - (BBCH 00-01) / PRE tretmani primijenjeni su tijekom istih faze rasta kao kod suncokreta (kod suhoga sjemena - početak imbibicije sjemena, faza suncokretova rasta) - (BBCH 00-01)

${ }^{c}$ Weed control efficacy was estimated within 28 DAAs and 56 DAAs DAAs / ${ }^{c}$ Djelotvornost suzbijanja korova procijenjena je 28 i 56 dana nakon primjene / Nadzor suzbijanja korova procijenjen je unutar 28 i 56 dana nakon primjene

dMeans followed by the same letter within a column are not significantly different according to Fisher's Protected LSD test at P<0.05 / Srednje vrijednosti iza kojih slijedi isto slovo unutar stupca nisu značajno različite prema Fisherovu zaštićenom LSD testu pri $P<0,05$

Sunflower injury. PRE-em herbicides were applied at the time when herbicide applications typically occur in North Macedonia sunflower production (Table 1) and are thus representative of producer practices and label recommendations. However, in 2018 in Bitola region heavy rainfall occurred in the first 10 days after PRE-em application and caused leaching of herbicides through the soil profile. It is highly possible that sunflower injury was due to higher amounts of rain $(57 \mathrm{~mm})$ directly following PRE-em herbicide treatments. Injury ranged from $9-28 \%$ across PRE-em treatments seven days after emergence (DAE). Injuries by oxyfluorfen and dimethenamid- $P$ were more serious $(24-28 \%$, respectively). Oxyfluorfen caused phytotoxicity symptoms like slight bleaching, leaf tip burn, and stunting of sunflower growth. Stunting of sunflower growth was recorded on the plots treated with dimethenamid as well. The injuries caused by other PRE-em herbicides decreased in seven and 21 DAAs, respectively (Table 6). However, the sunflower injuries inflicted by oxyfluorfen and dimethenamid were still evident in 21 DAEs. Jursík et al. (2015) had similar observations and concluded that the sunflower phytotoxicity caused by oxyfluorfen was the highest $(25-47 \%)$ without the effect of irrigation. Sunflower growth was inhibited, and regeneration was slow; however, the seed yield was not significantly reduced in any year. Similarly, in the study of Andr et al. (2017), the highest level of sunflower injury was recorded on plots 
treated by oxyfluorfen (18\%). The injury caused by oxyfluorfen on sunflower was mainly caused by raindrops bouncing from the soil surface, which contaminated leaves and caused necrosis and leaf deformation. Further, the sunflower tolerance to dimethenamid was good (phytotoxicity less than 7\%), except in the year when sunflower injury ranged from $10-12 \%$ across irrigation treatments. The sunflower injury caused by pendimethalin, aclonifen, and S-metolachlor was minimal (between 5-7\%) (Jursík et al., 2015).

Sunflower yield. Sunflower achene yields for each treatment in both regions generally reflected overall weed control and crop injury (Table 5). Comparison of weedy and weed-free control indicated that weeds reduced sunflower achene yield by $72-75 \%$ in the Bitola region, and $72-76 \%$ in the Titov Veles region for both years, respectively (Table 6). Similarly, Jaykumar et al. (1988), Elezović et al. (2012), and
Alves et al. (2013) reported that yield reduction due to weeds in sunflower is estimated to be between $70-81 \%$. A significant treatment by year interaction resulted in two distinct years for sunflower achene yield in the Bitola region. In both years, the lowest sunflower achene yield was recorded in untreated control plots (980 and $850 \mathrm{~kg} \mathrm{ha}^{-1}$, respectively). The lowest yield between PRE-em herbicides in 2018 was obtained in plots treated with aclonifen $\left(2030 \mathrm{~kg} \mathrm{ha}^{-1}\right)$. Not one of PRE-em applied herbicides yielded higher than the weed-free control, because sunflower yields were more closely related to percent of weed control. In 2019, the effective removal of the competitive effect of the weeds led to an increase of the participation of the yield components of the sunflower and as a result the sunflower yield in all PRE-em herbicide treatments significantly increased and resulted in yields similar to that of the weed-free control (Table 6).

Table 6. Sunflower plant injury as influenced by the PRE-em applied herbicides and the yield as influenced by the PRE-em applied herbicides in sunflower in the Bitola and Titov Veles region in 2018 and 2019.

Tablica 5. Oštećenja biljaka suncokreta pod utjecajem primijenjenih PRE-em herbicida i prinos pod utjecajem PRE-em primijenjenih herbicida u suncokretu u regiji Bitolj i Titov Veles u 2018. i 2019. godini.

\begin{tabular}{|c|c|c|c|c|c|c|c|c|c|c|c|c|c|}
\hline \multirow{4}{*}{$\begin{array}{l}\text { Treatments / } \\
\text { Tretmani }\end{array}$} & \multirow{4}{*}{$\begin{array}{c}\text { Rate } \\
\text { (g a. i./ } \\
\text { ha) / } \\
\text { Doza (g } \\
\text { aktivne } \\
\text { tvari /ha) }\end{array}$} & \multicolumn{6}{|c|}{ Bitola region / Regija Bitolj } & \multicolumn{6}{|c|}{ Titov Veles region / Regija Titov Veles } \\
\hline & & \multicolumn{4}{|c|}{$\begin{array}{c}\text { Sunflower injury / } \\
\text { Oštećenje suncokreta (\%) }\end{array}$} & \multirow{2}{*}{\multicolumn{2}{|c|}{$\begin{array}{c}\text { Seed yield / } \\
\text { Prinos sjemena } \\
\text { (kg/ha) }\end{array}$}} & \multicolumn{4}{|c|}{$\begin{array}{c}\text { Sunflower injury / } \\
\text { Oštećenje suncokreta (\%) }\end{array}$} & \multirow{2}{*}{\multicolumn{2}{|c|}{$\begin{array}{c}\text { Seed yield / } \\
\text { Prinos sjemena } \\
\text { (kg/ha) }\end{array}$}} \\
\hline & & \multicolumn{2}{|c|}{2018} & \multicolumn{2}{|c|}{2019} & & & \multicolumn{2}{|c|}{2018} & \multicolumn{2}{|c|}{2019} & & \\
\hline & & $\begin{array}{c}7 \\
\text { DAEs }\end{array}$ & $\begin{array}{c}21 \\
\text { DAEs }\end{array}$ & $\begin{array}{c}7 \\
\text { DAEs }\end{array}$ & $\begin{array}{c}21 \\
\text { DAEs }\end{array}$ & 2018 & 2019 & $\begin{array}{c}7 \\
\text { DAEs }\end{array}$ & $\begin{array}{c}21 \\
\text { DAEs }\end{array}$ & $\begin{array}{c}7 \\
\text { DAEs }\end{array}$ & $\begin{array}{c}21 \\
\text { DAEs }\end{array}$ & 2018 & 2019 \\
\hline $\begin{array}{l}\text { Weedy control / } \\
\text { Korovita kontrola }\end{array}$ & ----- & 0 & 0 & 0 & 0 & $980^{d}$ & $850^{\mathrm{e}}$ & 0 & 0 & 0 & 0 & $810^{d}$ & $950^{\mathrm{d}}$ \\
\hline $\begin{array}{l}\text { Weed-free control / } \\
\text { Beskorovna kontrola }\end{array}$ & $-\cdots--$ & 0 & 0 & 0 & 0 & $3490^{\mathrm{a}}$ & $3340^{\mathrm{abc}}$ & 0 & 0 & 0 & 0 & $3670^{\mathrm{a}}$ & $3410^{\mathrm{a}}$ \\
\hline Pendimethalin & 1365 & 11 & 7 & 0 & 0 & $2320^{\mathrm{b}}$ & $3390^{\mathrm{a}}$ & 0 & 0 & 0 & 0 & $3620^{a b}$ & $2740^{\text {bc }}$ \\
\hline Metobromuron & 1500 & 14 & 9 & 0 & 0 & $2090^{c}$ & $3220^{\mathrm{bcd}}$ & 0 & 0 & 0 & 0 & $3540^{\mathrm{bc}}$ & $2620^{\circ}$ \\
\hline Oxyfluorfen & 300 & 24 & 20 & 0 & 0 & $2170^{\mathrm{bc}}$ & $3330^{a b c}$ & 0 & 0 & 0 & 0 & $3680^{\mathrm{a}}$ & $2800^{b}$ \\
\hline Aclonifen & 2400 & 9 & 6 & 0 & 0 & $2030^{c}$ & $3145^{d}$ & 0 & 0 & 0 & 0 & $3505^{c}$ & $2650^{c}$ \\
\hline S-metolachlor & 1440 & 15 & 11 & 0 & 0 & $2270^{\mathrm{bc}}$ & $3350^{a b}$ & 0 & 0 & 0 & 0 & $3580^{\mathrm{abc}}$ & $2700^{b c}$ \\
\hline Dimethenamid-P & 1530 & 28 & 22 & 0 & 0 & $2080^{c}$ & $3210^{\text {cd }}$ & 0 & 0 & 0 & 0 & $3540^{\mathrm{bc}}$ & $2780^{b}$ \\
\hline LSD 0.05 & & & & & & 195.96 & 170.50 & & & & & 99.52 & 146.55 \\
\hline $\begin{array}{l}\text { Random effect } \\
\text { interactions PREem } \\
\text { herbicides } \\
\text { treatment x year } \\
\text { / Međudjelovanja } \\
\text { slučajnoga učinka } \\
\text { PRE-em tretman } \\
\text { herbicida x god. }\end{array}$ & & & & * & & & & & & $S$ & & & 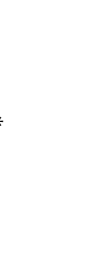 \\
\hline
\end{tabular}

aAbbreviation: PRE - preemergence; DAA - days after application; NS - not significant; * significant at a $5 \%$ level according to a Fisher's protected LSD test at

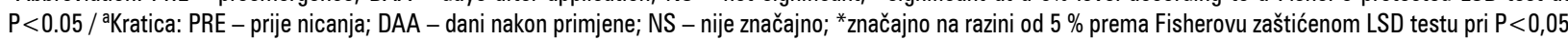
bPRE treatments were applied in the same growth stages as sunflower (at dry seed - beginning of seed imbibition in the sunflower growing stage - BBCH 00-01) / PRE tretmani primijenjeni su tijekom istih faza razvoja kao kod suncokreta (kod suhoga sjemena - početak imbibicije sjemena u fazi suncokretova rasta - BBCH 00-01)

'Sunflower injury was estimated seven and 21 days after emergence (DAEs) / ' Oštećenje suncokreta procijenjeno je sedam dana i 21 dan nakon nicanja (DAE) ${ }^{d}$ Means followed by the same letter within a column are not significantly different according to Fisher's Protected LSD test at $P<0.05 /{ }^{d}$ Srednje vrijednosti iza kojih slijedi isto slovo unutar stupca nisu značajno različite prema Fisherovu zaštićenom LSD testu pri $\mathrm{P}<0,05$ 
A significant treatment by year interaction resulted in two distinct years for sunflower yields in the Titov Veles region with PRE-em herbicides, as well. In 2018, sunflower yield was in line with that of weed-free control ranging from 810 to $3570 \mathrm{~kg} \mathrm{ha}^{-1}$. Aclonifen was the lowest-yielding herbicide treatment with $3505 \mathrm{~kg}$ $\mathrm{ha}^{-1}$, whereas oxyfluorfen was the highest-yielding herbicide treatment $\left(3680 \mathrm{~kg} \mathrm{ha}^{-1}\right)$. In the investigation by Pannacci et al. (2007), the highest average sunflower yields among PRE-em treatments were obtained in plots treated with s-metolachlor + oxyfluorfen $(720$ +168 and $960+144 \mathrm{~g} \mathrm{a}$. i. ha ${ }^{-1}$ ), S-metolachlor + aclonifen $\left(960+720 \mathrm{~g} \mathrm{a}\right.$. i. ha $\left.{ }^{-1}\right)$, and pendimethalin + imazamethabenz $\left(768+400 \mathrm{~g}\right.$ a. i. ha $\left.{ }^{-1}\right)$. Sunflower yields in pendimethalin and oxyfluorfen treated plots were 46 and $63 \%$ higher than in weedy control (Narender et al., 2017). Regardless of irrigation and sunflower injury, in all investigated PRE-em herbicides, yield was significantly higher in comparison to untreated control plots (Jursík et al., 2015). In 2019, sunflower grain yields following all PRE applied herbicides were significantly lower (between -610 and $-760 \mathrm{~kg} \mathrm{ha}^{-1}$ ) than weed-free control (Table 6).

A significant treatment by year interaction resulted in two distinct years for sunflower yields in Titov Veles region with PRE-em herbicides, as well. In 2018, the sunflower yields were on the line with that of weed-free control. It was ranged from 810 to $3570 \mathrm{~kg}$ $\mathrm{ha}^{-1}$. Aclonifen was the lowest-yielding herbicide treatment with $3505 \mathrm{~kg} \mathrm{ha}^{-1}$, whereas oxyfluorfen was the highest-yielding herbicide treatment $\left(3680 \mathrm{~kg} \mathrm{ha}^{-1}\right)$. In the investigation of Pannacci et al. (2007), the highest average sunflower yields among the PRE-em treatments were obtained on the plots treated with s-metolachlor + oxyfluorfen $\left(720+168\right.$ and $960+144$ g a. i. ha $\left.{ }^{-1}\right)$, S-metolachlor + aclonifen $\left(960+720 \mathrm{~g}\right.$ a. i. ha $\left.{ }^{-1}\right)$ and pendimethalin + imazamethabenz $(768+400 \mathrm{~g}$ a. i. $\left.\mathrm{ha}^{-1}\right)$. Sunflower yield in pendimethalin- and oxyfluorfen-treated plots was 46 and $63 \%$ higher than in the weedy control (Narender et al., 2017). Regardless of irrigation and sunflower injury, in all investigated PRE-em herbicides yield was significantly higher in comparison to untreated control plots (Jursík et al., 2015). In 2019, the sunflower grain yields following all PRE applied herbicides were significantly lower (between -610 and -760 $\mathrm{kg} \mathrm{ha}^{-1}$ ) than weed-free control (Table 6).

\section{CONCLUSION}

With the recent change of climatic conditions, the control of weeds with PRE-em herbicides has become quite difficult in sunflower. Therefore, it should be taken into account that before the use of PRE-em herbicides, the climatic conditions especially rainfall in different regions should be monitored. This has been confirmed based on the results achieved where some of the herbicides, depending on the rainfall and the year, have shown different efficacy in the control of weeds. In addition, some of the herbicides have had phytotoxic effects on the sunflower crop, due to heavy rainfall directly following PRE-em application in the Bitola region in 2018. In general, all weeds in 2018 in the Bitola region were poorly controlled due to the higher amount of rainfall during the first 10 days after herbicide application. Contrary, the efficacy of herbicides was weak for weed control in 2019 in the Titov Veles region, but this was due to drought conditions observed at this region in early and mid-spring 2019. The results obtained show that the lack of or heavy rainfall has an impact on the effectiveness of herbicides for the control of weeds in sunflower. The achene yields of sunflower in both regions generally has been influenced by the weed control and crop injury.

\section{REFERENCES}

1. Alves, G. D. S., Tartaglia, F. D. L., Rosa, J. C., Lima, P. C. D., Cardoso, G. D., \& Beltrão, N. E. D. M. (2013). Períodos de interferência das plantas daninhas na cultura do girassol em Rondônia. Revista Brasileira de Engenharia Agrícola e Ambiental, 17(3), 275-282. https://doi.org/10.1590/S1415-43662013000300005.

2. Andr, J., Kočárek, M., Jursík, M., Fendrychová, V., \& Tichý, L. (2017). Effect of adjuvants on the dissipation, efficacy and selectivity of three different pre-emergent sunflower herbicides. Plant Soil and Environment, 63(9), 409-415. https://doi.org/10.17221/365/2017-PSE.

3. Anonymous, (2000). Dual Magnum sample label. (2000). Crop Protection Reference. New York: C\&P Press. pp. 1647-1663.

4. Anonymous, (2008). Frontier $®$ Herbicide Product Label," Mississauga, ON, BASF Canada Inc., $17 \mathrm{p}$.

5. Armel, G. R., Wilson, H. P., Richardson, R. J., \& Hines, T. E. (2003). Mesotrione, acetochlor, and atrazine for weed management in corn (Zea mays). Weed Technology, 17(2), 284-290. https://doi.org/10.1614/08 90-037X(2003)017[0284:MAAAFW]2.0.C0;2.

6. Arnold, R. N., Smeal, D., Lombard, K. A., O'Neill, M. K., Allen, S. C., West, M., \& Yazzie, R. (2012). Broadleaf weed control in dry beans (Phaseolus vulgaris) with preemergence applications of valor alone or in combination from 2004 to 2008. Bulletin 804 . Agricultural Experiment Station, College of Agricultural, Consumer and Environmental Sciences, New Mexico State University.

7. Bergmann, H. (2016). Proman - a strong base for flexible herbicide strategies in potato production. 27 Deutsche Arbeitsbesprechung uber Fragen der Unkrautbiologie und-bekampfung, 23-25. Februar 2016 in Braunschweig.

8. Boerboom, C. M., Stolenberg, D. E., Jeschke, M. R., Trower T. L., \& Gaska, J. M. (2006). Factors affecting glyphosate control of common lambsquarters. In Proc. N. Cent. Weed Sci. Soc (Vol. 61, p. 54).

9. Bollman, S. L., \& Sprague, C. L. (2007). Optimizing $\mathrm{s}$-metolachlor and dimethenamid-P in sugarbeet microratetreatments. Weed Technology, 21(4), 1054-1063. https://doi.org/10.1614/WT-07-068.1. 
10. Brown, D., \& Masiunas, J. (2002). Evaluation ofherbicides for pumpkin (Cucurbita spp.). Weed Technology, 16(2), 282-292. https://doi.org/10.1515/helia.2001.24.35.11.

11. Chinnusamy, N., Chinnagounder, C., \& Krishnan, P. N. (2013). Evaluation of weed control efficacy and seed cotton yield in glyphosate tolerant transgenic cotton. American Journal of Plant Sciences, 4(6), 1159-1163. https://doi.org/10.4236/ajps.2013.46142.

12. Choi, J. S, Lee, H. J, Hwang, I. T, Pyon, J. Y., \& Cho, K. Y. (1999). Differential susceptibilities of wheat and barley to diphenyl ether herbicide oxyfluorfen. Pestic Biochem Physiology, 65(1), 62-72. https://doi.org/10.1006/pest.1999.2429.

13. Clewis, S.B. Everman, W.J. Jordan, D.L. Wilcut J.W. (2007). Weed management in North Carolina peanuts (Arachis hypogaea) with S-metolachlor, diclosulam, flumioxazin, and sulfentrazone systems. Weed Technology, 21(3), 629-635. https://doi.org/10.1614/WT-06-139.1.

14. El-Afifi, S., \& Lâng, F. (1981). Influence of metobromuron and chlorobromuron on the pigments of chloroplast and the photosynthetic activity of bean and pea seedlings. Proc. 21st Hung. Annu. Meet. Biochem., Veszprem, pp, 49.

15. Elezovic, I., Datta, A., Vrbnicanin, S., Glamoclija, D., Simic, M., Malidza, G., \& Knezevic, S. Z. (2012). Yield and yield components of imidazolinone-resistant sunflower (Helianthus annuus L.) are influenced by pre-emergence herbicide and time of post-emergence weed removal. Field Crops Research, 128, 137-146. https://doi.org/10.1016/j.fcr.2011.12.020.

16. Ferrell, M. A., Whitson, T. D., \& Miller, S. D. (2004). Basic guide to weeds and herbicides, The University of Wyoming, College of Agriculture, Department of Plant Sciences, Cooperative Extension Service, MP18, pp. 1-19.

17. Filipovski, G. (2006). Soil classification of the Republic of Macedonia. MASA, 313-323.

18. Frans, R. E., Talbert, R., Marx, D., \& Crowley, H. (1986). Experimental design and techniques for measuring and analyzing plant responses to weed control practices. In N.D. Camper ed. Research methods in weed science. 3rd ed. Champaign, IL: Southern Weed Science Society. pp, 37-38.

19. Fried, G., Chauvel, B., Reboud, X., Chollet, D., Bombarde, M., \& Delos, M. (2006). Flore adventice du tournesol. Phytoma la défense des végétaux, (596), 37-43.

20. Frost, P., \& Barnes, G. (2003). Evaluation of new herbicides for management of black nightshade (Solanum nigrum) in processing tomatoes. ISHS Acta Horticulturae., 613, VIII International Symposium on the Processing Tomato.

21. Haskins, B. (2012). Using pre-emergent herbicides in conservation farming systems NSW: The NSW Departmentof Primary Industries. https://www.dpi.nsw.gov.au/_data/ assets/pdf_file/0003/431247/Using-pre-emergentherbicides-in-conservation-farmingsystems.pdf.

22. Hatzinikolaou, A. S., Eleftherohorinos, G. S., \& Vasilakoglou, I. B. (2004). Influence of formulation on the activity and persistence of pendimethalin. Weed Technology, 18(2), 397-403. https://doi.org/10.1614/ WT-03-121R1.
23. Heatherly, L. G., \& Hodges, H. F. (1998). Soybean production in the Midsouth. CRC Press, Boca Raton, London, New York, Washington DC.

24. Inoue, M. H., Santana, D. C., Oliveira, Jr. R. S., Clemente, R. A., Dallacort, R., Possamai, A. C. S., Santana, C. T. C., \& Pereira, K. M. (2010). Leaching potential of herbicides used in cotton crop under soil column conditions. Planta Daninha, 28(4), 825-833. https://doi.org/10.1590/ S0100-83582010000400016.

25. Janak, T. W., \& Grichar, W. J. (2016). Weed control in corn (Zea mays L.) as influenced by preemergence herbicides. International Journal of Agronomy, Vol. 2016, 1-9. https://doi.org/10.1155/2016/2607671.

26. Jaykumar, R., Premsekar, M., Kempuchetty, N., \& Subramaniam, S. (1988). Effect of integrated weed management on yield and quality of sunflower. Madras Agricultural Journal, 75(3-4), 304.

27. Johnson, B. (1971). Effect of weed competition on sunflowers. Weed Science. 19(4), 378-380. https://doi. org/10.1017/S0043174500049183.

28. Jursík, M., Kočárek M., Hamouzová K., Soukup J., Venclová V. (2013). Effect of precipitation on the dissipation, efficacy and selectivity of three chloroacetamide herbicides in sunflower. Plant, Soil and Environment, 59(4), 175-182.

29. Jursík, M., Soukup, J., Holec, J., Andr, J., \& Hamouzová, K. (2015). Efficacy and selectivity of pre-emergent sunflower herbicides under different soil moisture conditions. Plant Protection Science, 51(4), 214-222. https://doi.org/10.17221/82/2014-PPS.

30. Khan, R. U., Morrison, I. N., \& Rashid, A. (1988). Grass weed control in sunflower in spring and kharif season under barani (rainfed) conditions in Pakistan. Crop Protection, 7(1), 9-15.

31. Kilinc, 0., Grasset, R., \& Reynaud, S. (2011). The herbicide aclonifen: The complex theoretical bases of sunflower tolerance. Pesticide Biochemistry and Physiology, 100(2), 193-198. https://doi.org/10.1016/j. pestbp.2011.04.001.

32. Kilinc, 0., Reynaud, S., Perez, L., Tissut, M., \& Ravanel, P. (2009). Physiological and biochemical modes of action of the diphenylether aclonifen. Pesticide Biochemistry and Physiology, 93(2). 65-71. https://doi.org/10.1016/j. pestbp.2008.11.008.

33. Le Baron, H. M., McFarland, J. E., Simoneaux, B. J., \& Ebert, E. (1988). Metolachlor. Pages 335-373 in P. C. Kerney and D. D. Kaufman, eds. Herbicides: Chemistry, Degradation, and Mode of Action. Volume 3. New York: Dekker.

34. Legha, P. K., Malik, R. K., \& Faroda, A. S. (1992). Weed management in Kharif sunflower Helianthus annus. Crop Research, 5(2), 376-378.

35. Lewis, D. W., Cavalieri, A., \& Gulden, R. H. (2016). Effect of biennial wormwood (Artemisia biennis) interference on sunflower yield and seed quality. Weed Science, 64(1), 154-160. https://doi.org/10.1614/WS-D-15-00076.1. 
36. Lewis, W. D., \& Gulden, R. H. (2014). Effect of kochia (Kochia scoparia) interference on sunflower (Helianthus annuus) yield. Weed Science, 62(1), 158-165. https://doi.org/10.1614/WS-D-13-00069.1.

37. Lin, H. T., Chen, S. W., Shen, C. J., \& Chu, C. (2007). Dissipation of pendimethalin in the garlic (Allium sativum L.) under subtropical condition. Bulletin of Environmental Contamination and Toxicology, 79(1), 84-86. https://doi.org/10.1007/s00128-007-9100-3.

38. Loux, M. M., Dobbels, A. F., Johnson, W. G., Nice, G. R., Bauman T. T., \& Stachler, J. M. (2008). Weed control guide for Ohio and Indiana, Ohio State University Extension Bulletin 789/Purdue Extension, Pub No. WS16, 2008, pp, 201.

39. Lyon, D. J., \& Wilson, R. G. (2005). Chemical weed control in dryland and irrigated chickpea. Weed Technology, 19(4), 959-965. https://doi.org/10.1614/WT-05-013R.1.

40. Mohseni-Moghadam, M., \& Doohan, D. (2015). Banana pepper response and annualweed control with S-metolachlor and clomazone. Weed Technology, 29(3), 544-549. https://doi.org/10.1614/WT-D-15-00015.1.

41. Moseley, M. C., \& Hagood, E. S. (1990). Reducing herbicide inputs whenestablishing no-till soybeans (Glycine max). Weed Technology, 4(1), 14-19. https://doi.org/10.1017/S0890037X00024891.

42. Nadasy, E., Nadasy, M., \& Nagy, V. (2008). Effect of soil herbicides on development of sunflower hybrid. Vol. 36, Supplement: Proceedings of the VII. Alps-Adria Scientific Workshop, 28 April-2 May 2008, Stara Lesna, Slovakia. Cereal Research Communications, 36, 847-850.

43. Narender, J., Padmaja, J., Srinivas, A., \& Sailaja, V. (2017). Effect of herbicides on yield and economics of sunflower (Helianthus annuus L.). International Journal of Pure Applied Bioscience, 5(4), 1582-1587. https://doi.org/10.18782/2320-7051.5604.

44. Osborne, T. B., Shaw, R. D., \& Ratliff, L.R. (1995). Soybean (Glycine max) cultivar tolerance to SAN $582 \mathrm{H}$ and metolachlor as influenced by soilmoisture. Weed Science, 43(2), 288-292. https://doi.org/10.1017/S0043174500081194.

45. Pacanoski, Z., Kolevska, D. D., \& Nikolovska, S. (2016). Floristic composition of the weeds and efficacy of PRE herbicides in a black locust (Robinia pseudoacacia L.) Nursery. Reforesta, 1(2), 22-31. https://doi.org/10.21750/REFOR.2.03.18.

46. Pannacci, E., \& Bartolini, S. (2018). Evaluation of chemical weed control strategies in biomass sorghum. Journal of Plant Protection Research, 58(4), 404-412. https://doi.org/10.24425/jppr.2018.125881.

47. Pannacci, E., \& Onofri, A. (2016). Alternatives to terbuthylazine for chemical weed control in maize. Communications in Biometry and Crop Science, 11(1), 51-63.

48. Pannacci, E., Graziani, F., \& Covarelli, G. (2007). Use of herbicide mixtures for pre and post-emergence weed control in sunflower (Helianthus annuus). Crop Protection, 26(8), 1150-1157. https://doi.org/10.1016/j.cropro.2006.10.008.
49. Park, S. J. \& Hamill, A.S. (1993). Response of common bean (Phaseolus vulgaris) cultivars to metobromuron. Weed Technology, 7(1), 70-75. https://doi.org/10.1017/S0890037X00036897.

50. Rainbow, R., \& Derpsch, R. (2011). Advances in no-till farming technologies and soil compaction managementin rainfed farming systems. In: Tow P, Cooper I, Partridge I, Birch C, editors. Rainfed Farming Systems, Springer Netherlands, pp, 991-1014.

51. Ramsey, F. L., \& Schafer, D. W. (1997). The statistical sleuth: A course in methods of data analysis. Belmont, CA, Duxbury. pp, 91-97.

52. Rapparini, G. (1996). II diserbo delle colture. Edizioni L'InformatoreAgrario, Verona, Italy, pp, 496 (Italian).

53. Reddy, A. M., Reddy, G. P., \& Reddy, D. S. (2008). Effect of crop-weed competition in sunflower. Research Crop, $9(3), 580-581$.

54. Reddy, K. N., \& Locke, M. A. (1996). Imazaquin spray retention, foliar washoff and runoff losses under simulated rainfall. Pesticide Science, 48(2), 179-187. https://doi. org/10.1002/(SICI)1096-9063(199610)48:2<179::AIDPS457>3.0.C0;2-M.

55. Serim, A.T., Asav, Ü., Türkseven, S.G., \& Dursun, E. (2018). Banded herbicide application in a conventional sunflower production system. Turkish Journal of Agriculture and Forestry, 42(5), 354-363. https://doi.doi:10.3906/tar-1712-95.

56. Soltani, N., Shropshire, C., \& Sikkema, P. H. (2015). Pendimethalin residues from weed managementin dry bean can cause injury in autumn seeded winter wheat. Agricultural Sciences, 6(1), 159-163. https://doi.org/10.4236/as.2015.61014.

57. Soukup J., Jursik M., Hamouz P., Holec J., \& Krupka J. (2004): Influence of soil pH, rainfall, dosage, and application timing of herbicide Merlin 750 WG (isoxaflutole) on phytotoxicity level in maize (Zea mays L.). Plant, Soil and Environment, 52(2), 88-94.

58. Steckel, L. E., Sprague, C. L., \& Hager, A. G. (2002). Common waterhemp (Amaranthus rudis) control in corn (Zea mays) with single preemergence and sequential applications of residual herbicides. Weed Technology, 16(4), 755-761. https://doi.org/10.1614/0890-037X(2002)016[0755:CWARCI]2.0.C0;2.

59. Trevisan, M., Capri, E., Cella, A., Errera, G., \& Sicbaldi, F. (1999). Field, laboratory and modelling studies to evaluate aclonifen soil fate. Toxicological \& Environmental Chemistry, 70(1-2), 29-47. https://doi.org/10.1080/02772249909358737.

60. Vencill, W. K. (2002). Herbicide Handbook. 8th ed. Lawrence, KS: Weed Science Society of America, $p p$, 493.

61. Vischetti, C., Marucchini, C., Leita, L., Cantone, P., Danuso, F., \& Giovanardi, R. (2002). Behaviour of two sunflower herbicides (metobromuron, aclonifen) in soil. European Journal of Agronomy, 16(3), 231-238. https://doi.org/10.1016/S1161-0301(01)00136-8.

62. Wanjari, R. H., Yaduraju, N. T., \& Ahuja, K. N. (2000). Critical period of weed competition in spring sunflower. Indian Journal of Weed Science, 32(1\&2), 17-20. 
63. Wilcut, J. W., York, A. C., \& Wehtje, G. R. (1994). The control and interaction of weeds in peanut (Arachis hypogaea). Reviews of Weed Science, 6, 177-205.

64. WSSA (Weed Science Society of America), (2014). Herbicide handbook of the Weed Science Society of America, Lawrence, KS, USA, Weed Science Society of America.
65. Zanatta, J. F., Procopio, S. 0., Manica, R., Pauletro, E. A., Cargnelutti, F. A., Vargas L., Sganzerla D. C., Rosenthal, M. D., \& Pinto, J. J. 0. (2008). Soil water contents and fomesafen efficacy in controlling Amaranthus hybridus. Planta Daninha, 26(1), 143-155. https://doi. org/10.1590/S0100-83582008000100015.

\section{NADZOR KOROVA U SUNCOKRETU (Helianthus annuus L.) ZEMLJIŠNIM HERBICIDIMA POD UTJECAJEM DUGOTRAJNIH I OGRANIĆENIH OBORINA}

\section{SAŽETAK}

Terenski su pokusi provedeni u regiji Bitolj i u regiji Titov Veles tijekom dviju sezona rasta suncokreta (2018. i 2019.) radi procjene nadzora korova u suncokretu zemljišnim herbicidima, pod utjecajem produljene i ograničene oborine. Polygonum aviculare L., Solanum nigrum L., Chenopodium album L., Amaranthus retroflexus $L$., Portulaca oleracea $L$. $i$ Echinochloa crus-galli (L.) P. Beauv. bili su najdominantniji korovi u objema regijama. Djelotvornost PRE-em herbicida varirala je među korovnim vrstama, tretmanima, periodima procjene djelotvornosti, regijama i godinama. Ukupne performanse PRE-em herbicida korelirane su $s$ vremenom i stanjima tla. Nestalni vremenski uzorci između dviju godina studije vjerojatno su utjecali na nadzor korova. Tijekom 2018. svi su korovi u regiji Bitolj bili slabo nadzirani $\mid<77 \% i<62 \%$, 28 odnosno 56 dana nakon primjene). Djelotvornost herbicida dala je 2019. samo marginalan nadzor korova i u regiji Titov Veles (< $68 \%$ i $<59 \%$, 28 odnosno 56 dana nakon primjene) zbog sušnih uvjeta promatranih u toj regiji u rano proljeće i sredinom proljeća. PRE-em primjena nakon koje je uslijedila obilna oborina rezultirala je 2018. oštećenjem suncokreta u regiji Bitolj, u rasponu od 9 do 28 \% tijekom PRE-em tretmana sedam dana nakon nicanja. Oštećenja oksifluorfenom i dimetenamidom-P bila su ozbiljnija (24 odnosno $28 \%$ ). Prinos sjemena suncokreta za svaki tretman u objema regijama u pravilu je odražavao ukupan nadzor korova i oštećenje usjeva.

Ključne riječi: PRE-em herbicidi, suncokret, korovi

(Received on February 12, 2021; accepted on September 13, 2021 - Primljeno 12. veljače 2021.; prihvaćeno 13. rujna 2021.) 